\title{
Peach Fruit Set and Buttoning after Spring Frost
}

\begin{abstract}
Chunxian Chen ${ }^{1}$, William R. Okie, and Thomas G. Beckman
U.S. Department of Agriculture, Agricultural Research Service, Southeastern Fruit and Tree Nut Research Lab, 21 Dunbar Road, Byron, GA 31008
\end{abstract}

Additional index words. Prunus persica, chill requirement, embryo abortion, tree-persisted button, stress-induced trait

\begin{abstract}
Peach fruit set is affected by cumulative chill and spring frost. A spring frost occurred on 29 Mar. 2015 at the U.S. Department of Agriculture, Agricultural Research Service (USDA-ARS) Byron station after 3 weeks of bloom, reducing fruit set and resulting in many buttons (abnormally small fruit with dead embryos). Fruit set was rated in 2014, 2015, and 2016 and button set rated in 2015 using the same scale $(0=$ no fruit/button to $9=1-2$ fruit/button at every node). The overall fruit set rating was substantially different in the 3 years, averaging 5.61 in 2014, 2.61 in 2015, and 6.04 in 2016. Buttons and skin-damaged fruit in 2015 varied among peach genotypes. Comparison of fruit and button set ratings showed that there was no difference between cultivars and selections, but some significant differences in fruit set for four ripening months, among the 3 years, and among the nine chilling classes, respectively. Among the cultivars, the most common button set rating was 0-3. For example, 'Sunprince', 'Loring', and 'Carored' trees had a high button set rating, whereas 'Flameprince', 'Julyprince', and 'Contender' trees were low. As for peach selections, BY04P1690n was among those with the highest button set rating. In the population derived from a cross of button-prone BY04P1690n and button-free BY99P3866w, fruit and button counts from 10 long fruiting shoots ranged from 4 to 53 fruit (21.63 on average) and 2 to 27 buttons (10.39 on average). The peach button rate ranged from $5.36 \%$ to $87.10 \%(30.70 \%$ on average). The range, distribution, and percentage of the button counts suggested that, if buttoning was genetically controlled, it appeared quantitative. Further assessment is needed.
\end{abstract}

Flowers and fruit can be damaged in the spring by frosts and freezes. When weather shelter air temperatures are above freezing, but night-time radiation allows exposed surface temperatures to drop below freezing, a frost (sometimes called radiational freeze) will occur when the dew point is reached. If shelter temperatures drop below freezing, the event is termed a freeze, which can be advective or radiational (Proebsting, 1982). The former is caused by a mass of cold air (usually from the Arctic); the latter by radiational cooling (http://www.aces.edu/dept/ peaches/frzweather.html). Spring frost, a frequent concern in many peach (Prunus persica)-growing areas, may freeze buds,

Received for publication 15 Mar. 2016. Accepted for publication 16 May 2016.

We thank Bryan Blackburn and Luke Quick for help in maintaining the materials used in this work. The research was partly supported by the U.S. Department of Agriculture National Program of Plant Genetic Resources, Genomics and Genetic Improvement (Project number: 6606-21000-004-006) and Georgia Agriculture Commodity Commission for Peaches (Project number: 58-6042-5-002). This article reports the results of research only.

Mention of a trademark or proprietary product is solely for the purpose of providing specific information and does not constitute a guarantee or warranty of the product by the USDA and does not imply its approval to the exclusion of other products that may also be suitable.

${ }^{1}$ Corresponding author. E-mail: chunxian.chen@, ars.usda.gov. blooming flowers, and fertilized fruitlets causing them to brown and abscise, and can dramatically affect peach fruit set (Rieger et al., 1991; Smith et al., 1994). A late spring frost can wipe out an entire peach crop. A mild spring frost may be helpful by thinning the fruitlets naturally, because many peach cultivars have been selected for high flower density, and heavy thinning is often needed to yield desirable fruit size and quality (Milatovic et al., 2010; Reighard and Byers, 2005; Schupp et al., 2008). Although frost damage to crops is often mentioned in media reports, studies on peach tolerance to natural frost remain very limited largely because natural frost, along with its potential damage, occurs unpredictably (Assmann et al., 2008; Rieger et al., 1991; Smith et al., 1994). Utilization of artificial frost to assess peach frost tolerance is possible but has apparent limitations (Szalay et al., 2000). An evaluation of 17 peach/nectarine and 8 Japanese plum (Prunus salicina) cultivars after a natural frost of $\approx-3{ }^{\circ} \mathrm{C}\left(26.6^{\circ} \mathrm{F}\right)$ suggested frost tolerance during bloom varied significantly among these genotypes based on the ovary survival of recently opened flowers. Among the most tolerant were the peach cultivars Junegold and Coronet and the plum cultivars Bruce and Santa Rosa. Among the least tolerant were the peach cultivar Loring, the nectarine cultivar Fantasia, and the plum cultivar Ozark Premier (Rieger et al., 1991). Another assessment on fruit damage in 28 peach genotypes of different maturity after $\mathrm{a}-1.1^{\circ} \mathrm{C}$ natural frost also indicated that frost tolerance differed among the genotypes based on measures of percent fruit drop, suture diameter change, and other growth indices. Those genotypes with good leafing and hard endocarp (pit) at the time of frost incidence showed more apparent tolerance to frost damage. Fruit size also played a role in fruitlet survival. Fruit with suture diameter $>30 \mathrm{~mm}$ were more tolerant than those $<20 \mathrm{~mm}$ (Assmann et al., 2008). An artificial freezing test on six peach cultivars during dormancy revealed Venus was the most sensitive and the other five had a similar level of cold tolerance. In addition, the cold tolerance of flower buds was the highest in midDecember and the $\mathrm{LT}_{50}$ (lethal temperature for $50 \%$ death) was between -20 and $-25^{\circ} \mathrm{C}$, with no difference among the cultivars at the time. In the other dormant months, the tolerance decreased and the $\mathrm{LT}_{50}$ increased substantially (Szalay et al., 2000). Blossom thinning and fruit thinning to moderate crop densities can influence the cold tolerance of peach flower buds in late winter to some extent. For instance, following spring flower buds on the bottom half of shoots on blossom-thinned trees were more cold tolerant than those on trees hand thinned at $68 \mathrm{~d}$ after full bloom (Byers and Marini, 1994). Horticultural management delaying peach bloom could help reduce late spring frost damage (Reeder and Bowen, 1977).

Spring frost damage to plants is an interaction of temperature exposure and flower or fruitlet tenderness (Proebsting, 1982). Freeze-damaged flowers and fruitlets may drop or persist. When flowers/fruitlets are completely frozen and damaged, the epidermis (skin), mesocarp (flesh), endocarp (stone or pit), and embryo tissue (seed enclosed in the pit) turn brown quickly and fruit drop off trees in a week or so (Rieger et al., 1991). Some partly injured fruitlets may persist on trees, appear healthy and color normally, but stop enlarging. Hence they are colloquially called "buttons." They have apparently normal epidermis, mesocarp, and endocarp tissue (Connors, 1922). Therefore, the live tissues are enough of a sink to allow them to persist on the tree, but the dead embryo results in slower fruit development and reduced size. At the time of commercial greenfruit thinning (typically $\approx 30 \mathrm{~d}$ past bloom), buttons resemble healthy fruitlets in appearance and size, making it extremely difficult for growers to distinguish them from healthy fruitlets during the thinning process. As a result, useless buttons may be retained, reducing marketable yield. The issue appears only under certain spring frost conditions, making it difficult to regularly assess. Peach cultivars that are found to be prone to buttoning in a specific area, such as Keystone, are not replanted (Okie, 1998). However, when widespread buttoning occurs, it provides an opportunity to establish a standardized measuring procedure, assess variability for this characteristic among peach genotypes, and explore the possible heritability among available segregating populations. Moreover, genetic assessment of this 
issue in elite peach breeding lines could facilitate varietal improvement in the long run. A severe spring frost occurred on 29 Mar. $2015, \approx 1$ week after peak peach bloom in central Georgia. Flowers on commercial cultivars were at petal fall with very few unopened buds remaining. The frost reduced fruit set, with varying percentages of freezedamaged buttons persisting on trees in the USDA-ARS station peach breeding orchards, providing a valuable research opportunity on the button issue. The purpose here is to compare fruit set in 3 years and to report the impact of the frost on peach crop load and buttoning among cultivars, selections, and hybrids.

\section{Materials and Methods}

Peach materials. All materials used in this study were part of the USDA-ARS peach breeding collection and maintained in orchards at the USDA-ARS Southeastern Fruit and Tree Nut Research Station, Byron, GA. Reported results include 24 cultivars (Table 1), 38 selections, and 52 hybrid seedlings from a cross between a buttonprone selection BY04P1690n and a buttonfree selection BY99P3866w. All the cultivars and selections were grafted on 'Guardian' rootstock and grown according to commercial recommendation in the same orchard. They were pruned and thinned annually by a commercial crew, except in 2015 where no thinning was done due to the spring frost described below. However, the hybrid seedlings, planted in another orchard, were not pruned or thinned. Most of the cultivars/ selections, along with seedlings, have been under annual evaluation since they began fruiting and these evaluation records have been helpful in tracking some important environment-sensitive traits among genotypes, such as button occurrence, frost tolerance, blooming, and ripening time.

Weather and chill requirement data. Weather data were automatically collected at the Byron weather station $(\approx 1 \mathrm{~km}$ from orchard) and maintained in the Georgia weather network website (http://www. georgiaweather.net/index.php). The recorded weather shelter temperature on 29 Mar. 2015 was $-1.8^{\circ} \mathrm{C}\left(28.7^{\circ} \mathrm{F}\right)$. The exposed low temperature monitored in an adjacent orchard was $-3.3{ }^{\circ} \mathrm{C}\left(26.1^{\circ} \mathrm{F}\right)$. As a result of the freezing air temperature and little wind, a frost (radiation freeze) developed. Figure 1 shows the low and high temperatures recorded from March 2014, 2015, and 2016, respectively (Fig. 1A), and cumulative chill (hours when temperatures $\leq 7.2^{\circ} \mathrm{C}$ ) and heat $\left({ }^{\circ} \mathrm{C} /\right.$ days when temperatures $>7.2{ }^{\circ} \mathrm{C}$ ) given in the website from October 2013-14, 2014 15, and 2015-16, respectively (Fig. 1B). The chill requirement for the 24 cultivars was previously described (Okie, 1998) and used in this study (Table 1). The chill requirement data were used to assess the effect of blooming time on fruit and button set.

Normal-sized fruit set and button set rating. Typical, normal-sized mature fruit of thinned commercial peach scion cultivars and selections are larger than $50 \mathrm{~mm}$ in diameter while seed-aborted buttons are much less than half of the normal size, making them easily distinguishable at harvest. Fruit in between these sizes are relatively rare. A scale of $0-9$ was used to visually rate normal-sized fruit set (crop load) and button set on a tree when the normal fruit was commercially ripe. The rating scale ranged from $0=$ no fruit to $9=$ 1-2 fruit at every node, based on four trees for most lines. The rating of 7 was equivalent to the commercially thinned, desired crop load. Button set was rated independently of normal-sized fruit, but on the equivalent scale ranging from $0=$ no button to $9=1-2$ buttons at every node.

Normal-sized fruit set and button set in an $F_{1}$ population and its parents. Fruit and button set was also rated on parents BY04P1690n and BY99P3866w and their progeny. Ten long fruiting shoots with fruit and/or buttons were randomly selected, and buttons and normal-sized fruit were counted. Peach button percentage for each individual was calculated by dividing each button count by the sum of the fruit and button count.

Statistical analysis. Statistical analysis was performed in SAS 9.3 (SAS Institute Inc., Cary, NC). The GLM (general linear models) was used for ANOVA (analysis of variance) and Duncan's multiple range test for the significance of differences in fruit and button set between the cultivars and selections, among the four ripening months, and among the 3 years $(\alpha=0.05)$. The CORR (correlation) procedure was used to calculate correlation coefficients and $R^{2}$ values between any two datasets and the statistical significance of correlation was at $P<0.05$.

Table 1. Twenty-four peach cultivars and their estimated chill requirement (hours $<7.2^{\circ} \mathrm{C}$ ), approximate ripening months at Byron, fruit set rating (scale $0-9$ ) in 2014, 2015, and 2016 and button set rating in 2015 (scale 0-9). ${ }^{\mathrm{z}}$

\begin{tabular}{|c|c|c|c|c|c|c|}
\hline$\overline{\text { Cultivar }}$ & Chill requirement & Ripening mo. & Fruit set $2014^{y}$ & Fruit set 2015 & Button set 2015 & Fruit set $2016^{x}$ \\
\hline Carored & 550 & May & 3 & 1 & 3 & 8 \\
\hline Juneprince & 600 & June & 5 & 0 & 0 & 8 \\
\hline Goldprince & 650 & June & 1 & 2 & 2 & - \\
\hline Junegold & 650 & June & 2 & 1 & 2 & 8 \\
\hline Springprince & 650 & May & 3 & 1 & 2 & 8 \\
\hline GaLa & 750 & June & 3 & 4 & 2 & 7 \\
\hline Summergold & 750 & July & 4 & 1 & 2 & - \\
\hline Loring & 750 & June & 4 & 1 & 3 & - \\
\hline Scarletpearl & 750 & May & 6 & 1 & 1 & - \\
\hline Sunland & 750 & June & 7 & 5 & 2 & 8 \\
\hline Sunprince & 800 & July & 5 & 5 & 3 & 2 \\
\hline O’Henry & 800 & August & 4 & 2 & 0 & 5 \\
\hline Blazeprince & 850 & June & 7 & 3 & 0 & 7 \\
\hline Fireprince & 850 & June & 5 & 3 & 0 & 6 \\
\hline Flameprince & 850 & August & 6 & 3 & 0 & 6 \\
\hline Julyprince & 850 & July & 8 & 4 & 1 & 7 \\
\hline Redglobe & 850 & July & 7 & 6 & 1 & 5 \\
\hline Scarletprince & 850 & July & 8 & 5 & 1 & 7 \\
\hline Augustprince & 850 & August & 6 & 2 & 2 & 5 \\
\hline Rubyprince & 850 & June & 2 & 1 & 0 & 7 \\
\hline Summerprince & 900 & June & 7 & 1 & 1 & 7 \\
\hline Sureprince & 900 & June & 5 & 3 & 2 & 8 \\
\hline Cresthaven & 950 & August & 7 & 4 & 1 & 4 \\
\hline Contender & 1,050 & July & 7 & 6 & 0 & 3 \\
\hline
\end{tabular}

${ }^{\mathrm{z}}$ Low fruit set ratings of those low-chill cultivars may be affected by a less severe spring frost incidence occurring on 26 Mar. 2014 when the shelter temperature was $-1.5^{\circ} \mathrm{C}\left(29.3^{\circ} \mathrm{F}\right)$ at Byron, GA.

${ }^{\mathrm{y}}$ Fruit and button set was rated independently with the same scale range from $0=$ no fruit/button to $9=1-2$ fruit/button at every node, based on four trees for most lines. The fruit set rating of 7 was equivalent to the commercially thinned, desired crop load.

${ }^{x}$ Most fruit set ratings are high as no frost or freeze occurred in the spring of 2016 (Fig. 1A). The cumulative chill was only $886 \mathrm{~h}$ until Mar. 2016 , as shown in Fig. 1B, suggesting it might be insufficient for some high-chill materials. Fruit set ratings (lines) were absent for these crossed or dead trees. 

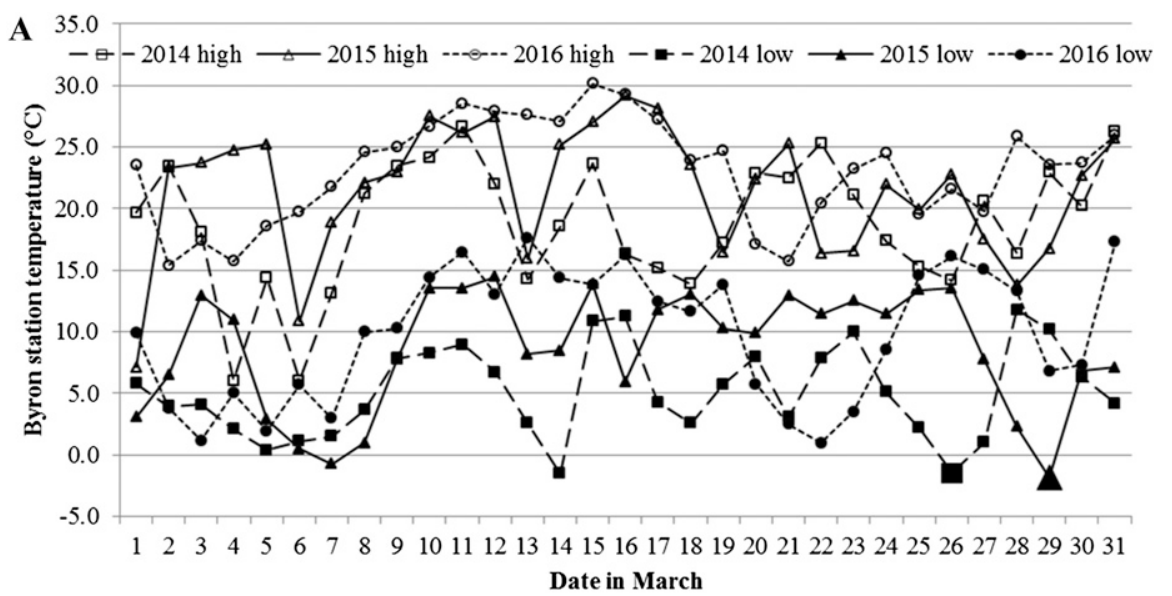

B

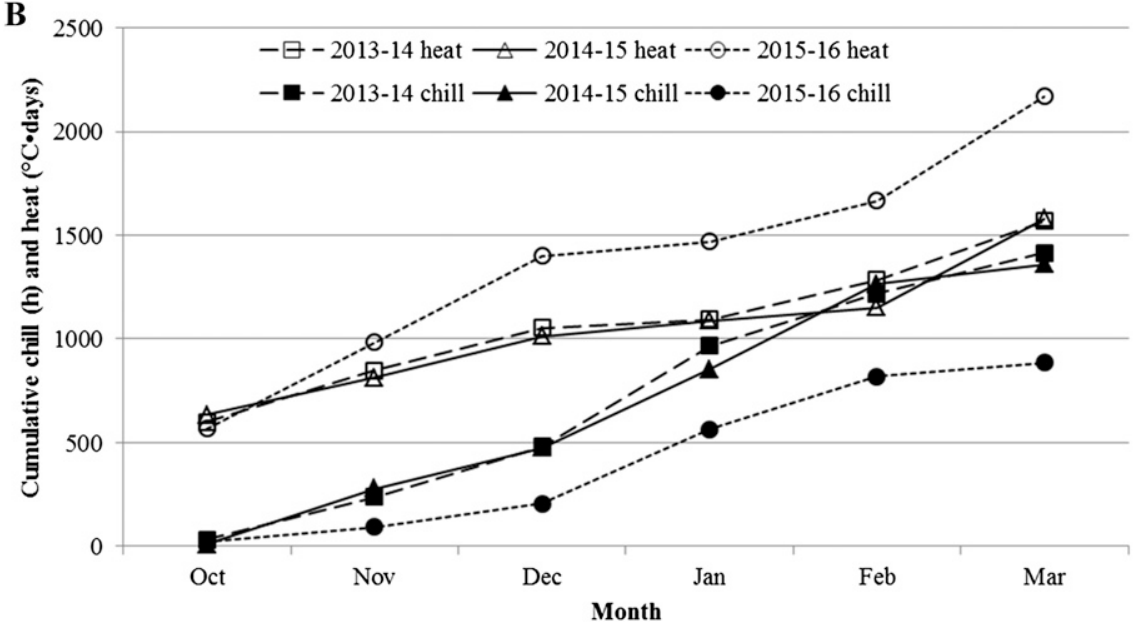

Fig. 1. (A) Daily low and high temperatures in March 2014, 2015, and 2016. (B) Cumulative chill (hours when temperatures $\left.\leq 7.2{ }^{\circ} \mathrm{C}\right)$ and heat $\left({ }^{\circ} \mathrm{C} /\right.$ days when temperatures $\left.>7.2^{\circ} \mathrm{C}\right)$ from October $2013-14$, 2014-15, and 2015-16. The commercial peach bloom time at the U.S. Department of Agriculture, Agricultural Research Service Byron station in 2015 was about from the last week of February to the first 2 weeks of March and the spring frost occurred on 29 Mar. 2015 (enlarged triangle point) when the low temperature inside the weather station shelter was $-1.8^{\circ} \mathrm{C}\left(28.7^{\circ} \mathrm{F}\right)$. A less severe spring frost incidence also occurred on 26 Mar. 2014 (enlarged rectangle point) when the shelter temperature was $-1.5^{\circ} \mathrm{C}\left(29.3^{\circ} \mathrm{F}\right)$ at Byron, GA. The Winter of $2015-16$ was relatively warm without late frosts, and the chill hours appeared insufficient for some high-chill materials.

\section{Results}

Observation on spring-frost-affected flowers, fruitlets, buttons, and embryos. The spring frost occurred at the station shortly after $\approx 3$ weeks of blooming when most flowers had dropped their petals and fruitlets were developing. The damage to flowers and fruitlets was devastating. Most open blossoms wilted quickly, turned brown, and fell off the tree (Fig. 2A). The fate of fruitlets borne on some early blooming cultivars and selections appeared to be associated with their size. Those bigger fruitlets appeared to have survived while a majority of smaller fruitlets turned brown and wilted gradually, then fell off the tree (Fig. 2B). The surviving fruitlets had four possible outcomes, depending on the survival of their embryo and the intact nature of their skin. If their embryo was killed, they fell off at some point or persisted and became buttons (Fig. 2C-E). These buttons were practically impossible for growers to visually discriminate for removal frost. In addition, buttons were found on many selections/cultivars although the percentage varied (Fig. 3). No button set rating was done in 2014 and 2016 as buttons were few and only noted for those incidences in the evaluation notes. The differences in buttons among peach genotypes suggested that the tendency to button could be a quantitative genetic trait. However, the appearance of numerous buttons is rare although spring frosts are common in this growing region and climate. Apparently, the stage of fruit development and low temperatures experienced were particularly conducive to producing buttons in 2015. From the research standpoint, more cases of buttons produced under natural or simulated conditions could help answer these relevant questions.

Comparison of fruit and button set rating showed that there was no difference between cultivars and selections, but some significant differences in fruit set for four ripening months, between the 2 years, and among chill requirements, respectively (Table 2 ). In general, fruit set was higher in high-chill materials than low-chill materials in 2014 and 2015, but not in 2016, suggesting the reduction in set was related to frosts rather than other factors such as bud density. However, unlike fruit set, button set did not show the same association with chill requirement, implying the formation of buttons may be an independent result of frost damage. Fruit set in these cultivars/selections ripening in July and August were higher than that in May and June, suggesting early ripening cultivars appeared more vulnerable to spring frost damage because they usually had lower chill requirement and bloomed earlier. The average fruit set rating in 2015 (2.61) was significantly lower than that in 2014 (5.61) and 2016 (6.04), which was consistent with the spring frost damage in 2015. Among the cultivars, button set ratings ranged from 0 to 3 (Table 1). For example, 'Sunprince', 'Loring', and 'Carored' trees showed higher button set rating, whereas 'Flameprince', 'Julyprince', and 'Contender' trees were low in button set rating. As for peach selections, BY04P1690n was among those with the highest button set ratings.

It was positive correlations between any pair of ripening month, chill requirement, fruit set 2014, and fruit set 2015; whereas it was negative correlations between any pair with button set in 2015 or fruit set in 2016 (Table 3). Among the highest positive coefficients were between the chill requirement, fruit set 2014, and fruit set 2015, which supported the relationship between chill requirement and fruit set in these cultivars. It was unclear how to interpret these negative correlations with button set in 2015 or fruit set in 2016; probably because button set and fruit set in 2015 were somewhat mutually exclusive at higher rating levels (Fig. 3) and insufficient chill hours in 2015-16 yielded low fruit set in some high-chill cultivars that usually were rather reliable in high-chill years (Fig. 1B). 


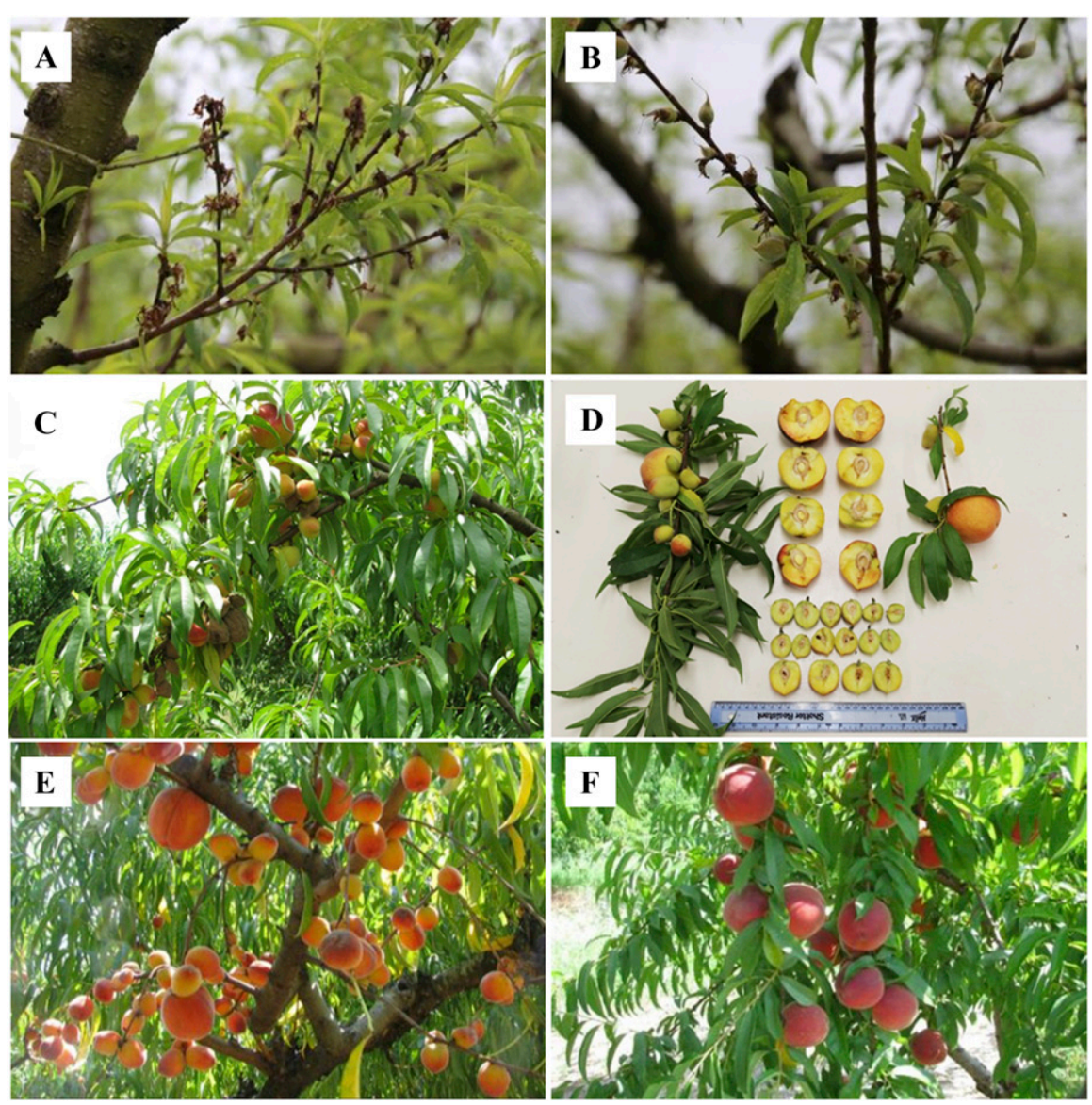

Fig. 2. Spring frost affected flowers, fruitlets, buttons, and normal fruit at the U.S. Department of Agriculture, Agricultural Research Service station at Byron, GA, in 2015. (A) freeze-damaged flowers browning and withering entirely, including the pistil, which will not produce a viable peach; (B) freeze-damaged fruitlets with varying degree of browning; (C) freeze-damaged peach fruit with pigmented, misshaped, cracked, and/or brown rot colonized skin; (D) fruiting shoots with buttons and longitudinal fruit sections. The top four: nearly normal size with fractured/misshaped skin and the greenish living seed inside the stony endocarp (pit); the bottom eight: buttons with the shriveled black dead seed in the tiny pits (the ruler provides a size scale); (E) A selection predominantly with buttons with normal blush and intact appearance; $(\mathbf{F})$ healthy peach fruit of normal size and blush (Photo credit: Chunxian Chen, A and $\mathbf{B}$ on 6 Apr. 2015; $\mathbf{C}$ and $\mathbf{D}$ on 12 June 2015; and $\mathbf{E}$ and $\mathbf{F}$ on 23 July 2015.)

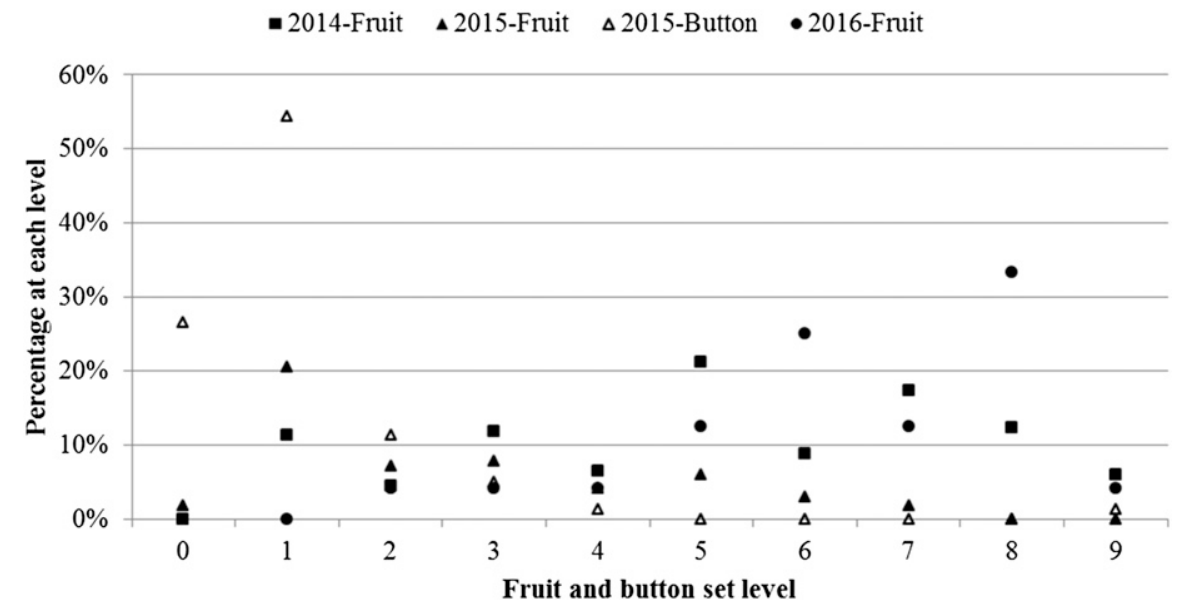

Fig. 3. Overall peach fruit and button set rating on 24 cultivars and 38 selections. Fruit set rating is a standard evaluation procedure in the breeding program. Button set rating was only collected in 2015 when a severe spring frost occurred and resulted in a large number of buttons. Fruit and button set was rated independently with the same scale range from $0=$ no fruit/button to $9=1-2$ fruit/button at every node, based on four trees for most lines. The fruit set rating of 7 was equivalent to the commercially thinned, desired crop load.
Fruit and button count in a seedling population. In a segregating population from button-prone and button-free parents, the sum of fruit and button counts from 10 long fruiting shoots varied widely (Fig. 4), in a range of 4 to 53 fruit ( 21.63 on average) and 2 to 27 buttons (10.39 on average). The peach button percentage, which ranged from $5.36 \%$ to $87.10 \%$ (30.70\% on average), showed an apparently normal distribution. The range and distribution of the peach button counts and percentages suggested that based on this small population, if the trait was genetically controlled, it was quantitative. Fruit set in 2016 was high for all seedlings (data not shown), suggesting differences in previous years were due to frost tolerance rather than setting ability in general. Further assessment of the buttoning issue is needed in the future.

\section{Discussion}

Dissecting evaluation of spring frost tolerance in peach. Cumulative chill and spring frost critically impact on peach marketable yield and also complicate orchard horticultural management. In this study, substantial frost damage and fruit set reduction in these cultivars and selections of all chill classes at the USDA-ARS station were observed due to the frost incidence on 29 Mar. 2015. In 2014 and 2015, fruit set generally was higher in high-chill materials than lowchill materials, and in 2016, fruit set was low in the high-chill (950 and $1050 \mathrm{~h}$ ) materials, suggesting that the chill requirement is associated with the reliability of fruit set. These materials with lower chilling requirement $(<850 \mathrm{~h})$ tended to have lower fruit set, and fruit set levels between 2014 and 2015 displayed a significant positive correlation (coefficient $=0.57, R^{2}=0.32$ ) $($ Table 3$)$. Around 800 chill hours in 2016 appeared insufficient for the two classes of high-chill materials (Fig. 1B), which might lead to low fruit set. Other factors such as flower bud number and previous fruit set may also be involved. Fruit set reduction was due to the loss (drop) of damaged fruitlets, which served as a good evaluation indicator for frost tolerance. Frost tolerance is a term often used to represent the biological ability of plants to withstand moderately freezing temperatures (Wisniewski et al., 2014). Because of the trait's complexity, freezing condition variability (e.g., freezing temperature durability), and inconsistent occurrences, there has been no standardized rating or phenotyping measure developed to better evaluate or more accurately represent frost tolerance among peach genotypes. Various measures have been used to indicate the tolerance or damage in peach (Assmann et al., 2008; Rieger et al., 1991; Szalay et al., 2000). For example, the ovary survival rate in recently opened flowers was used to assess frost tolerance (Rieger et al., 1991). Several fruitlet and shoot growth measures, including fruitlet number and size, pit hardness, sprout percentage, etc., were also used for the tolerance evaluation (Assmann et al., 2008). Although completely frozen and 
Table 2. Means and statistical significance of fruit and button set rating levels by analysis of variance. ${ }^{\mathrm{z}}$

\begin{tabular}{|c|c|c|c|c|c|c|}
\hline & & \multirow{2}{*}{$\frac{2014}{\text { Fruit set }}$} & \multicolumn{2}{|c|}{2015} & \multirow{2}{*}{$\frac{2016}{\text { Fruit set }}$} & \multirow{2}{*}{$\frac{3 \text { years }}{\text { Fruit set }}$} \\
\hline & & & Fruit set & Button set & & \\
\hline & 2015 & - & - & - & - & $2.61 \mathrm{~b}$ \\
\hline Material type & Selection & $6.08 \mathrm{a}$ & $2.50 \mathrm{a}$ & $1.11 \mathrm{a}$ & $5.88 \mathrm{a}$ & $4.71 \mathrm{a}$ \\
\hline \multirow{2}{*}{ Ripening mo. } & May & $3.86 \mathrm{~b}$ & $1.57 \mathrm{~b}$ & $1.43 \mathrm{a}$ & $6.67 \mathrm{a}$ & $3.90 \mathrm{~b}$ \\
\hline & June & $5.47 \mathrm{ab}$ & $2.44 \mathrm{ab}$ & $1.11 \mathrm{a}$ & $6.13 \mathrm{a}$ & $4.64 \mathrm{ab}$ \\
\hline \multirow[t]{7}{*}{ Chill requirement } & 550 & $3.00 \mathrm{ab}$ & $1.00 \mathrm{~b}$ & $3.00 \mathrm{a}$ & $8.00 \mathrm{a}$ & $4.00 \mathrm{a}$ \\
\hline & 600 & $5.00 \mathrm{ab}$ & $0.00 \mathrm{~b}$ & $0.00 \mathrm{~b}$ & $8.00 \mathrm{a}$ & $4.33 \mathrm{a}$ \\
\hline & 650 & $2.00 \mathrm{~b}$ & $1.33 \mathrm{~b}$ & $2.00 \mathrm{ab}$ & $8.00 \mathrm{a}$ & $3.25 \mathrm{a}$ \\
\hline & 750 & $4.80 \mathrm{ab}$ & $2.40 \mathrm{ab}$ & $2.00 \mathrm{ab}$ & $7.50 \mathrm{a}$ & $4.25 \mathrm{a}$ \\
\hline & 800 & $4.50 \mathrm{ab}$ & $3.50 \mathrm{ab}$ & $1.50 \mathrm{ab}$ & $3.50 \mathrm{c}$ & $3.83 \mathrm{a}$ \\
\hline & 850 & $6.13 \mathrm{ab}$ & $3.38 \mathrm{ab}$ & $0.63 \mathrm{~b}$ & $6.25 \mathrm{ab}$ & $5.25 \mathrm{a}$ \\
\hline & 900 & $6.00 \mathrm{ab}$ & $2.00 \mathrm{ab}$ & $1.50 \mathrm{ab}$ & $7.50 \mathrm{a}$ & $5.17 \mathrm{a}$ \\
\hline
\end{tabular}

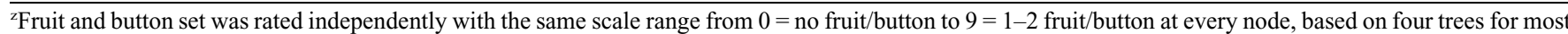
lines. The fruit set rating of 7 was equivalent to the commercially thinned, desired crop load. The differences in fruit set and button set levels were compared using the data of the 3 years separately and combined. Means suffixed with the same letter in the three independently compared groups, evaluation years (2014, 2015, and 2016), cultivar/selection, ripening months (May, June, July, and August), and chill requirement (550-1050 h below $7.2^{\circ} \mathrm{C}$ ), are not significantly different $(\alpha=0.05)$. The button set data were not collected in 2014 and 2016 as it was not an issue.

Table 3. Correlation coefficients and $R^{2}$ values (inside the parentheses) among chill requirement hours, ripening months, fruit set in 2014, 2015, and 2016, and button set in 2015 in peach cultivars. ${ }^{z}$

\begin{tabular}{lllll}
\hline & Ripening mo. & Chill requirement & Fruit set 2014 & Fruit set 2015 \\
\hline Chill requirement & $0.55(0.31)^{* *}$ & & & \\
Fruit set 2014 & $0.39(0.16)^{*}$ & $0.63(0.39)^{* * *}$ & & \\
Fruit set 2015 & $0.42(0.18)^{*}$ & $0.59(0.34)^{* *}$ & $0.57(0.32)^{* *}$ & $-0.09(0.01)$ \\
Button set 2015 & $-0.28(0.08)$ & $-0.45(0.21)^{*}$ & $-0.34(0.12)$ & $-0.55(0.30)^{* *}$ \\
Fruit set 2016 & $-0.67(0.44)^{* * *}$ & $-0.57(0.33)^{* *}$ & $-0.29(0.08)$ & $0.09(0.01)$ \\
\hline
\end{tabular}

${ }^{\mathrm{z}}$ The statistical significance of correlations was at $P<0.05(*), 0.01(* *)$, or $0.005(* * *)$. The numeral for each ripening month was used for the calculation, for example, 5 for May, etc.

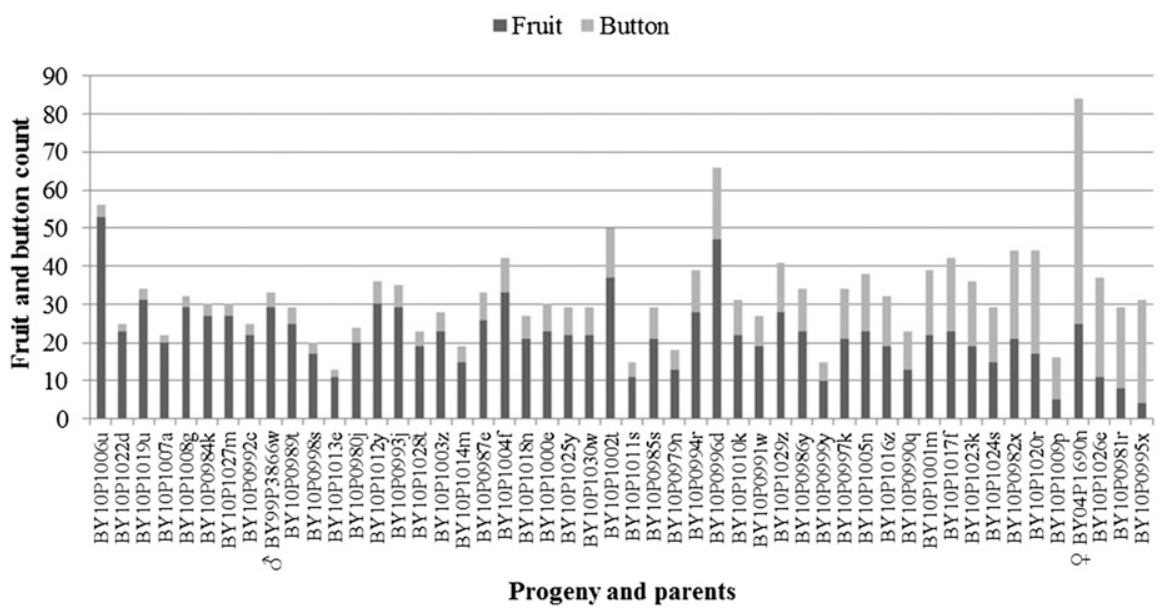

Fig. 4. Peach fruit and button count. This seedling population was derived from button-prone BY04P1690n ( + , seed parent) and button-free BY99P3866w ( $\mathcal{o}^{\wedge}$, pollen parent), respectively. The individuals are in an order based on their peach button percentage calculated by each individual button count divided by the sum of the fruit and button count.

dropped fruitlets were the primary cause for the reduction, buttons and skin-damaged fruit with normal sizes were the two other main contributing forms. Levels of spring frost tolerance among peach genotypes ultimately are related to degrees of frost damage. In other words, a healthy fruitlet affected by spring frost could develop into four fates: dropped fruitlet, small button, normally sized skin-damaged fruit, or normal marketable fruit. As observed in this and other studies, quick fruitlet drop was primarily due to a freezing injury to the entire fruitlet, including skin, flesh, pit, and embryo tissue (Rieger et al., 1991). A button or normally sized skin-damaged fruit could develop if frost damage caused only embryo abortion or skin microfracture, respectively. A frost tolerant peach would need to minimize loss to all three of these possible outcomes.
Genetic aspects of buttons in peach. In this study, variations were observed in buttons among peach genotypes and also in a population of hybrids from a cross of button-prone and button-free parents. In addition, several genetically related cultivars shared high button incidences. For example, 'Sunprince' and 'Goldprince' are descendants from 'Loring' that appears vulnerable to cold damage (Okie, 1998) and prone to buttoning in this station (Chen et al., unpunished data). According to this study, the formation of buttons appears independent of fruit set reduction and cultivars' chill requirement; which also coincide with the fact that dramatic fruit set reduction is observed more often than massive button formation when a hard spring frost occurs. These results suggest the occurrence of peach buttons was heritable but expressed only under certain freezing conditions. The critical temperature, duration, and type of a frost can cause different levels of damage to fruitlets (http:// www.aces.edu/dept/peaches/frzcritical.html). Formation of buttons in peach occurs when frost is cold enough to kill only embryos, apparently the most vulnerable part in fruitlets. It is worth noting that buttons may also form without frost when embryos abort due to some pollination issues in a cultivar (Connors, 1922), which is a completely different phenomenon. Button set or percentage may be a useful quantification measure for embryo-associated frost tolerance. Further 
studies of the environment-induced quantitative trait in peach will depend on the occurrence of similar frost events that are capable of inducing buttons on certain genotypes differing in frost tolerance, as shown in this study and previous reports (Assmann et al., 2008; Rieger et al., 1991; Szalay et al., 2000). In this context, spring frosts, from a breeding perspective, are a valuable opportunity to observe differences in buttoning and other frost-associated traits that are not regularly expressed among peach genotypes. Fruit and button set ratings under such circumstances can be very helpful to identify peach genotypes with potentially more frost tolerance and, therefore, the least risk of crop loss and/ or production of useless buttons. Those materials with the least fruit set reduction and button formation (presumably two independent events) might have higher frost tolerance, a preferred asset for further evaluation for release and use of parents in breeding. Further genetic mapping of the trait should be very helpful for breeding to circumvent frost damage (Hansche, 1990; Tittarelli et al., 2009). Some important genes related to cold acclimation have been cloned and characterized. For example, a full-length dehydrin gene, ppdhn1, was isolated from peach, and its expression was associated with cold hardiness differences in sibling genotypes of evergreen and deciduous peach (Artlip et al., 1997). The 60-kDa peach dehydrin protein (PCA60), generally induced in response to a wide array of environmental stresses, was also purified and demonstrated some antifreeze activity (Wisniewski et al., 1999). Some transcription factors apparently play a major role in sensing low temperature, inducing coldregulated gene expression, and initiating cold acclimation (Wisniewski et al., 2011). These advances hold great promise for the improvement of cold hardiness in economically important crops in the future (Wisniewski et al., 2014).

\section{Literature Cited}

Artlip, T.S., A.M. Callahan, C.L. Bassett, and M.E. Wisniewski. 1997. Seasonal expression of a dehydrin gene in sibling deciduous and evergreen genotypes of peach (Prunus persica [L] Batsch). Plant Mol. Biol. 33:61-70.

Assmann, A.P., I. Citadin, M.C. Locatelli, S. Scariot, M.A. Danner, and M.D.B. Raseira. 2008. Fruit frost tolerance in peach. Rev. Bras. Frutic. 30:1030-1035.

Byers, R.E. and R.P. Marini. 1994. Influence of blossom and fruit thinning on peach flower bud tolerance to an early spring freeze. HortScience 29:146-148.

Connors, C.H. 1922. Fruit setting on the J. H. Hale peach. Proc. Amer. Soc. Hort. Sci. 19:147-151

Hansche, P.E. 1990. Heritability of spring bloom and fall leaf abscission dates in Prunus persica. HortScience 25:1639-1641.

Milatovic, D., D. Nikolic, and D. Durovic. 2010. Variability, heritability and correlations of some factors affecting productivity in peach. Hort. Sci. 37:79-87.

Okie, W.R. 1998. Handbook of peach and nectarine varieties: Performance in the southeastern United States and index of names, p. 714. U.S. Dept. Agr., Agr. Hdbk.

Proebsting, E.L. 1982. Cold resistance of stone fruit flower buds. Washington State Univ. Coop. Ext. PNW Bul. 221.
Reeder, B.D. and H.H. Bowen. 1977. Delaying peach bloom to minimize late spring freeze damage. HortScience 12:230-230.

Reighard, G.L. and R.E. Byers. 2005. Peach thinning, p. 85-90. In: D.L. Horton and D. Johnson (eds.). Southeastern peach growers' handbook. The Univ. Georgia, Athens, GA.

Rieger, M., S. Lu, and M. Duemmel. 1991. Frost tolerance of some peach and Japanese plum cultivars. Fruit Var. J. 45:3-6.

Schupp, J.R., T.A. Baugher, S.S. Miller, R.M. Harsh, and K.M. Lesser. 2008. Mechanical thinning of peach and apple trees reduces labor input and increases fruit size. HortTechnology 18:660-670.

Smith, M.W., B.L. Carroll, and G.G. Taylor. 1994. Cold injury of peach and nectarine cultivars after a fall freeze. HortScience 29:821.

Szalay, L., J. Papp, and Z. Szabo. 2000. Evaluation of frost tolerance of peach varieties in artificial freezing tests. Acta Hort. 538:407-410.

Tittarelli, A., M. Santiago, A. Morales, L.A. Meisel, and H. Silva. 2009. Isolation and functional characterization of cold-regulated promoters, by digitally identifying peach fruit cold-induced genes from a large EST dataset. BMC Plant Biol. 9:121.

Wisniewski, M., A. Nassuth, C. Teulieres, C. Marque, J. Rowland, P.B. Cao, and A. Brown. 2014. Genomics of cold hardiness in woody plants. Crit. Rev. Plant Sci. 33:92-124.

Wisniewski, M., J. Norelli, C. Bassett, T. Artlip, and D. Macarisin. 2011. Ectopic expression of a novel peach (Prunus persica) CBF transcription factor in apple (Malus $\mathrm{x}$ domestica) results in short-day induced dormancy and increased cold hardiness. Planta 233:971-983.

Wisniewski, M., R. Webb, R. Balsamo, T.J. Close, X.M. Yu, and M. Griffith. 1999. Purification, immunolocalization, cryoprotective, and antifreeze activity of PCA60: A dehydrin from peach (Prunus persica). Physiol. Plant. 105:600-608. 